\title{
ANALISIS STRATEGI KOMUNIKASI PUBLIC RELATIONS DALAM MEMBANGUN DAN MEMPERTAHANKAN POLA HUBUNGAN MASYARAKAT
}

\author{
Adrian Fairuzi $^{1, \boxminus)}$, Ridwan Roy Tutupoho ${ }^{2}$, Anwar Mustofa ${ }^{3}$ \\ Administrasi Bisnis Terapan, Politeknik Negeri Jakarta \\ Email: ${ }^{1}$ fairuziadrian@gmail.com
}

\begin{abstract}
The purpose of this study was to analyze the public relations communication strategy of Aston Priority Simatupang Hotel \& Conference Center in building and maintaining community relationship. This study used a qualitative approach with descriptive methods, non-participant observation, and triangulation of sources. The object of this study is the Aston Priority Simatupang Hotel \& Conference Center. Secondary data were collected through documentation of public relations activities. The results of this study indicate that the Aston Priority Simatupang Hotel \& Conference Center has implemented a public relations communication strategy using online and offline media in building relationships with the community. The results of the implementation of the public relations communication strategy show that the Aston Priority Simatupang Hotel \& Conference Center has increased engagement and occupancy by $60 \%$ due to information provided through the media and the public's enthusiasm for the activities created by public relations has increased.
\end{abstract}

Keywords : Communication Strategy, Community Relationship, Public Relations

\begin{abstract}
ABSTRAK
Tujuan penelitian ini adalah untuk menganalisis strategi yang diterapkan oleh public relations Aston Priority Simatupang Hotel \& Conference Center dalam membangun dan mempertahankan pola hubungan masyarakat. Penelitian ini menggunakan pendekatan kualitatif dengan metode deskriptif, observasi non-partisipan, dan triangulasi sumber. Objek penelitian ini yaitu Aston Priority Simatupang Hotel \& Conference Center. Hasil yang dicapai dari penelitian ini menunjukan bahwa Aston Priority Simatupang Hotel \& Conference Center telah menerapkan strategi komunikasi public relations dengan menggunakan media online dan offline dalam membangun hubungan dengan masyarakat. Hasil dari penerapan strategi komunikasi public relations menunjukan bahwa Aston Priority Simatupang Hotel \& Conference Center mendapatkan engagement dan occupancy yang meningkat hingga $60 \%$ akibat informasi yang diberikan melalui media dan antusiasme masyarakat terhadap kegiatan yang dibuat oleh public relations meningkat.
\end{abstract}

Kata Kunci: Hubungan Masyarakat, Strategi Komunikasi, Public Relation

\section{PENDAHULUAN}

Public Relations pada era globalisasi saat ini memiliki peranan penting bagi perusahaan, karena seorang public relations merupakan jembatan penting untuk membangun hubungan perusahaan dengan masyarakat. Dalam langkah untuk membangun pola komunikasi dan hubungan kepada masyarakat, mewajibkan public relations menggunakan strateginya agar pola hubungan masyarakat dengan perusahaan tetap terjalin sebagaimana mestinya.

Menurut Harlow dalam Ruslan (2010:16) mengatakan bahwa Public Relations (PR) adalah fungsi manajemen yang khas dan mendukung pembinaan, pemeliharaan jalur bersama antara organisasi dengan publiknya, menyangkut aktivitas komunikasi, 
pengertian, penerimaan dan kerja sama yang melibatkan manajemen dalam menghadapi persoalan atau permasalahan, membantu manajemen dalam mengikuti dan memanfaatkan perubahan secara efektif; bertindak sebagai sistem peringatan dini dalam mengantisipasi kecenderungan penggunaan penelitian serta teknik komunikasi yang sehat dan etis sebagai sarana utama.

Public relations dapat dikatakan sebagai jembatan dalam perusahaan untuk menciptakan hubungan dengan siapa saja yang dapat memberikan keuntungan bersama serta untuk kemajuan perusahaan. Public relations mempunyai peran penting dalam segala bidang sesuai dengan fungsinya, yakni membentuk hubungan yang baik antara organisasi dengan publiknya, baik itu publik internal maupun publik eksternal.

Seorang public relations perusahaan wajib memiliki konsep untuk tetap menjalin hubungan komunikasi dengan masyarakat, konsep tersebut bisa melalui media sosial, media periklanan, atau website. Selain itu public relations juga bisa membuat konsep acara yang meliputi pihak perusahaan dan juga masyarakat dengan tujuan untuk membangun kepercayaan dan memperkuat pola hubungan dan komunikasi yang terjalin dengan masyarakat.

Dengan menjalin komunikasi publik yang baik dengan masyarakat, bisa menyebabkan perubahan persepsi yang dialami masyarakat kepada perusahaan. Kepercayaan masyarakat terhadap perusahaan akan memberikan kesan positif perusahaan. Jika hal ini terjadi, maka keuntungan perusahaan secara otomatis meningkat dan derajat perusahaan secara otomatis akan meningkat.

Aston Priority Simatupang Hotel \& Conference Center adalah sebuah hotel berbintang 4 yang berkecimpung dalam dunia bisnis dan penginapan, Aston Priority Simatupang Hotel \& Conference Center berada di bawah naungan group Archipelago International yang memiliki tujuan untuk membantu konsumen mengembangkan karir mereka dan menciptakan serta mengoperasikan hotel "terbaik di kelasnya".

Permasalahan saat ini dalam membangun dan mempertahankan hubungan dengan masyarakat bagi hotel adalah terdapat beragam respons negatif dari masyarakat melalui Online Travel Agent (OTA). Hal tersebut juga dikarenakan di dalam OTA tersebut terdapat unsur Electronic Word of Mouth (e-WOM) yang disebabkan oleh berbagai kalangan masyarakat sehingga dapat mempengaruhi pemikiran masyarakat lain terhadap hotel.

Berikut merupakan hasil perbandingan review negatif yang didapatkan Aston Priority Simatupang Hotel \& Conference Center dengan lima hotel bisnis pesaing yang terdapat di daerah Jakarta Selatan dan sekitarnya dari tahun 2017 hingga tahun 2019 melalui Online Travel Agent.

Tabel 1. Hasil Review Negatif Aston Priority Simatupang Hotel \& Conference Center dan Lima Hotel Pesaing

\begin{tabular}{lccc}
\hline HOTEL & \multicolumn{3}{c}{ TAHUN } \\
\cline { 2 - 4 } & 2017 & 2018 & 2019 \\
\hline $\begin{array}{l}\text { Aston } \\
\text { Priority }\end{array}$ & 13 & 28 & 26 \\
Swiss- & 35 & 24 & 21 \\
Belinn & & & \\
Grand & 46 & 31 & 35 \\
Whiz & & & \\
Mercure & 4 & 6 & 14 \\
IBIS Styles & - & - & 64 \\
Margo Hotel & 27 & 39 &
\end{tabular}

Sumber: Online Travel Agent TripAdvisor, Traveloka, Agode, Pegi-Pegi (2020)

Oleh karena itu seorang public relations perusahaan wajib mempertahankan pola komunikasi perusahaan terhadap 
masyarakat dengan tujuan untuk membangun kepercayaan masyarakat kepada perusahaan dan membangun pola komunikasi perusahaan kepada masyarakat yang hilang diakibatkan oleh dampak respons negatif yang diberikan mengenai perusahaan.

\section{Tujuan Penelitian}

1. Untuk mengetahui dan menganalisis strategi komunikasi public relations untuk membangun dan mempertahankan pola hubungan masyarakat.

2. Untuk mengetahui pengaruh strategi komunikasi public relations dalam membangun pola hubungan masyarakat yang hilang terhadap perusahaan.

3. Untuk mengetahui strategi komunikasi public relations Aston Priority Simatupang Hotel \& Conference Center dalam menghadapi review negatif yang diberikan oleh masyarakat.

\section{Manfaat Penelitian}

\section{Perusahaan}

Bagi perusahaan atau instansi, khususnya Kepala Departemen dapat menjadikan penelitian ini sebagai bahan masukan dan gambaran mengenai pengaruh public relations dalam meningkatkan pola hubungan masyarakat.

2. Dunia Ilmu Pengetahuan

Hasil penelitian ini diharapkan dapat memberi kontribusi akademis dalam Jurusan Administrasi Niaga, Program Studi Administrasi Bisnis Terapan mengenai pentingnya komunikasi dalam perusahaan untuk membangun hubungan dengan masyarakat.

3. Bagi Peneliti

Bagi peneliti diharapkan dapat meningkatkan pengetahuan mengenai teori public relations dalam kehidupan sehari-hari. Dan dapat meningkatkan kemampuan dan pengetahuan mengenai strategi komunikasi yang tepat untuk membangun pola hubungan masyarakat sehingga memiliki bekal di kemudian hari pada saat menjalankan pekerjaan di perusahaan.

\section{Rumusan Masalah}

1. Bagaimana strategi komunikasi public relations yang efektif dalam membangun dan mempertahankan hubungan antara masyarakat dengan Aston Priority Simatupang Hotel \& Conference Center?

2. Bagaimana strategi yang diterapkan public relations dalam membangun pola hubungan yang hilang dan mampu mempertahankan kepercayaan masyarakat terhadap perusahaan?

3. Bagaimana strategi public relations Aston Priority Simatupang Hotel \& Conference Center dalam menghadapi review negatif yang diberikan oleh masyarakat?

\section{Tinjauan Pustaka \\ Strategi}

Definisi strategi yang dikemukakan oleh Jauch \& Glueck dalam Akdon (2011:13) menyebutkan bahwa Strategi adalah rencana yang disatukan, menyeluruh dan terpadu yang mengaitkan keunggulan strategi organiasi dengan tantangan lingkungan dan dirancang untuk memastikan bahwa tujuan utama organisasi dapat dicapai melalui pelaksanaan yang tepat oleh organisasi.

\section{Strategi Komunikasi}

Middleton dalam Hafiea, (2013:61) mendefinisikan bahwa strategi komunikasi adalah kombinasi yang terbaik dari semua elemen komunikasi mulai dari komunikator, komunikan, pesan, dan media yang di rancang untuk mencapai tujuan komunkasi yang optimal. 


\section{Public Relations}

Definisi public relations menurut Jefkins dalam Morrisan (2010:8) adalah sesuatu yang merangkum keseluruhan komunikasi yang terencana, baik itu ke dalam maupun keluar antara suatu organisasi dengan khalayaknya dalam rangka mencapai tujuan-tujuan spesifik yang berlandaskan pada saling pengertian.

\section{METODE PENELITIAN}

Tempat penelitian ini dilaksanakan di Aston Priority Simatupang Hotel \& Conference Center yang terletak di Jl. Let. Jend TB Simatupang No.Kav. 9, RT.2/RW.2, Kebagusan, Kecamatan Pasar Minggu, Kota Jakarta Selatan, Daerah Khusus Ibukota Jakarta. Tujuan penulis melakukan penelitian di tempat tersebut dengan pertimbangan bahwa perusahaan tersebut merupakan hotel yang berfokus pada bidang MICE (Meeting, Incentive, Convention, dan Exhibition) dan satu-satunya hotel yang berada di kawasan Arkadia Business Park Jakarta Selatan.

Jenis penelitian yang digunakan dalam penelitian ini adalah metode penelitian dengan pendekatan kualitatif deskriptif. Peneliti menggunakan jenis penelitian kualitatif karena untuk mengetahui strategi komunikasi yang dilakukan oleh public relations Aston Priority Simatupang Hotel \& Conference Center untuk membangun dan mempertahankan pola hubungan masyarakat.

\section{Teknik Pengumpulan Data}

Metode pengumpulan data primer yang digunakan dalam penelitian ini adalah data yang dihasilkan dari observasi dan wawancara mendalam (in depth interview) antara penulis dengan informan dari pihak Aston Priority Simatupang Hotel \& Conference Center. Sedangkan pengumpulan data sekunder yang digunakan dalam penelitian ini adalah data berupa hasil dokumentasi kegiatan dan campaign melalui media sosial dan media massa Aston Priority Simatupang Hotel \& Conference Center.

\section{Teknik Pengolahan Data}

Teknik pengolahan data dalam penelitian ini adalah sebagai berikut: analisa deskriptif mengenai hasil wawancara dengan informan, editing yaitu meneliti kembali data-data yang sudah ada, dan klasifikasi yaitu pengelompokan seluruh data.

\section{Teknik Analisis Data}

Teknik analisis data dalam penelitian ini adalah analisis induktif, Analisis data induktif adalah penarikan kesimpulan yang berangkat dari fakta-fakta khusus, untuk kemudian ditarik kesimpulan secara umum. Langkah selanjutnya adalah reduksi data yaitu merangkum, memilih hal-hal yang pokok, memfokuskan pada hal-hal yang penting, dicari tema dan polanya dan membuang hal yang tidak perlu. Langkah selanjutnya adalah menyajikan data-data yang telah direduksi ke dalam laporan secara sistematis. Dan langkah selanjutnya adalah melakukan teknik triangulasi sumber, yaitu mendapatkan data dari sumber yang berbeda-beda dengan teknik yang sama. Dan langkah terakhir adalah kesimpulan dan verifikasi.

\section{HASIL DAN PEMBAHASAN}

Hasil dari penelitian yang berjudul Strategi Komunikasi Public Relations dalam Membangun dan Mempertahankan Pola Hubungan Masyarakat menunjukan bahwa public relations menggunakan strategi komunikasi yang dapat diklasifikasikan menjadi 2 unsur yaitu:

\section{a. Traditional}

Strategi komunikasi traditional merupakan komunikasi yang tidak berfokus kepada penggunaan teknologi. 
Melainkan menggunakan media offline, media cetak, event internal dan eksternal yang melibatkan masyarakat secara langsung.

\section{b. Non Traditional}

Strategi komunikasi non traditional merupakan strategi komunikasi yang berfokus kepada penggunaan teknologi dan digital seperti blasting email, media sosial, pemberitaan melalui media online dan ini merupakan fokus utama public relations dalam membangun hubungan dengan masyarakat karena mengikuti perkembangan teknologi yang semakin maju sehingga memudahkan public relations untuk berkomunikasi dengan masyarakat.

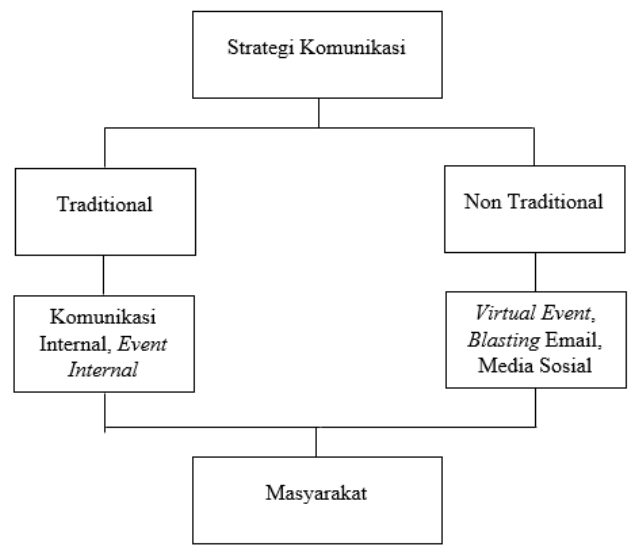

Gambar 1. Strategi Komunikasi Traditional dan Non Traditional (Sumber: hasil data olahan)

Hasil dari penerapan strategi komunikasi public relations menunjukan bahwa Aston Priority Simatupang Hotel \& Conference Center mendapatkan engagement dan occupancy yang meningkat hingga 60\% akibat informasi yang diberikan melalui media dan antusiasme masyarakat terhadap kegiatan yang dibuat oleh public relations meningkat.

Akan tetapi dalam upaya membangun dan mempertahankan pola hubungan masyarakat, public relations Aston Priority Simatupang Hotel \& Conference Center memiliki kelebihan dan tantangan dalam mengimplementasikannya. Kelebihan nya adalah banyak masyarakat yang tertarik dengan package yang telah dipromosikan melalui media elektronik dan cetak, selain itu banyak masyarakat yang antusias terhadap event calendar yang telah dibuat, dan pihak perusahaan mendukung penuh terhadap campaign strategy yang dibuat oleh public relations Aston Priority Simatupang Hotel \& Conference Center.

Tantangan nya adalah public relations harus membuat event yang inovatif dan menarik, tentu hal tersebut merupakan salah satu tantangan dikarenakan public relations harus membuat konsep yang menyangkut kepada seluruh kalangan masyarakat dari berbagai umur. Konsep yang harus dibuat oleh public relations Aston Priority Simatupang Hotel \& Conference Center harus memiliki kesan yang menarik dan menggunakan event sebagai alat untuk mempromosikan hotel.

Berdasarkan hasil wawancara dengan informan, informan mengatakan bahwa review negatif yang diberikan oleh masyarakat memberikan pengaruh terhadap rating hotel, sebelum nya Aston Priority Simatupang Hotel \& Conference Center berada diranking 38, namun dikarenakan review negatif yang diberikan oleh masyarakat, peringkat Aston Priority Simatupang Hotel \& Conference Center turun ke peringkat 77 dari 854 hotel yang ada di ibu kota Jakarta. Dari segi revenue juga berpengaruh tetapi tidak terlalu signifikan karena ketidakpuasan masyarakat berbeda-beda, ketidakpuasan tersebut bisa mengarah kepada fasilitas, ada juga masyarakat yang tidak puas dengan service dan makanan, dan ada masyarakat yang tidak puas dengan layanan kamar yang diberikan.

Upaya public relations dalam mempertahankan pola hubungan masyarakat yang memberikan review negatif terhadap hotel melalui Online 
Travel Agent adalah dengan membalas review negatif yang diberikan oleh masyarakat yakni dengan cara membalas review tersebut sesuai fakta, public relations akan memberikan fakta yang sedang terjadi kepada masyarakat baik dari segi kondisi dan situasi yang ada di dalam hotel dengan tujuan untuk memberikan kejelasan dan informasi kepada masyarakat agar tidak terjadi kesalahpahaman antara masyarakat dengan hotel.

Upaya public relations dalam membangun kepercayaan masyarakat yang hilang adalah dengan cara terlebih dahulu membuat data mengenai masyarakat yang memberikan review negatif lalu menyebarkan kembali informasi atau promo yang ada melalui email dengan tujuan agar membangun ketertarikan kembali.

\section{KESIMPULAN DAN SARAN}

\section{Kesimpulan}

Public relations menerapkan strategi komunikasi dengan menggunakan media baik media cetak maupun elektronik. Selain menggunakan media, public relations Aston Priority Simatupang Hotel \& Conference Center membuat kegiatan berupa event calendar dengan melibatkan masyarakat sekitar untuk membangun hubungan secara langsung dengan masyarakat.

Strategi yang dilakukan untuk membangun pola komunikasi yang hilang akibat review negatif yang diberikan, public relations melakukan pendataan terlebih dahulu terkait masyarakat yang memberikan review negatif. Setelah itu public relations memberikan informasi dan promo yang ada di dalam hotel melalui email dengan tujuan untuk membangun ketertarikan kembali.

Upaya dalam mempertahankan pola hubungan dengan masyarakat yang memberikan review negatif kepada hotel melalui online travel agent dan upaya dalam meningkatkan ranking hotel, public relations menggunakan strategi yakni dengan cara membalas pesan-pesan yang diberikan oleh masyarakat terkait hotel sesuai dengan fakta yang ada, public relations Aston Priority Simatupang Hotel \& Conference Center menganggap bahwa review negatif yang diberikan masyarakat memiliki tujuan yang baik untuk membantu perusahaan berinovasi dan memperbaiki kesalahan-kesalahan yang sudah dilakukan sebelumnya.

\section{Saran}

Berdasarkan hasil pembahasan dan kesimpulan yang telah dipaparkan diatas, berikut merupakan saran yang peneliti sampaikan yaitu sebagai berikut:

1. Disarankan kepada pihak hotel agar lebih memperhatikan evaluasi terhadap strategi komunikasi yang telah dilakukan. Sebab evaluasi inilah yang akan menjadi kunci keberhasilan strategi yang telah diterapkan oleh public relations Aston Priority Simatupang Hotel \& Conference Center. Apabila strategi telah berjalan dengan baik, tentunya patut untuk dipertahankan. Namun apabila strategi yang diterapkan gagal, diperlukan strategi lain yang lebih akurat dan efektif yang dapat dilakukan oleh public relations hotel.

2. Kepada peneliti lain yang akan melakukan penelitian dengan topik yang sama disarankan untuk melakukan wawancara yang lebih mendalam, tidak hanya kepada pihak hotel saja, melainkan juga kepada pengunjung Aston Priority Simatupang Hotel \& Conference Center untuk mengetahui efek komunikasi yang dilakukan oleh public relations terhadap masyarakat dan mengetahui feedback yang diberikan masyarakat kepada hotel. 


\section{DAFTAR PUSTAKA}

[1] Abdullah, Yudi. Oktarina, Yetty. 2017. Komunikasi Dalam Perspektif Teori dan Praktik. Yogyakarta. Deepublish

[2] Abidin, Yusuf Zainal. 2015. Manajemen Komunikasi: Filosofi, Konsep dan Aplikasi. Bandung. CV. Pustaka Setia

[3] Agus, Sulastiyono. 2011. Manajemen Penyelanggaraan Hotel. Bandung. Alfabeta.

[4] Akbar, Purnomo Setiady dan Husaini Usman. 2012. Pengantar Statistika. Jakarta. Bumi Aksara

[5] Akdon, 2011, Strategic Management For Educational Management. Bandung. Alfabeta

[6] Ardianto, Elvinaro. 2011. Metodologi Penelitian untuk Public Relations Kuantitatif dan Kualitatif. Bandung. Simbiosa Rekatama Media.

[7] Arni, Muhammad. 2015. Komunikasi Organisasi, Jakarta. Bumi Aksara.

[8] Danandjaja. 2011. Peranan Humas dalam Perusahaan, Yogyakarta. Graha Ilmu.

[9] David, Fred R, 2011. Strategic Management, Jakarta. Salemba Empat.

[10] Devito, Joseph A. 2011. Komunikasi Antar Manusia. Pamulang. Karisma Publishing Group

[11]Effendy, Onong Uchjana. 2015. Ilmu, Komunikasi Teori dan Praktek Komunikasi. Bandung. Citra Aditia Bakti.

[12] Hermawan, Agus. 2012. Komunikasi Pemasaran. Jakarta. Erlangga

[13] Liliweri, Alo. 2011. Komunikasi: Serba Ada Serba Makna. Jakarta. Prenada Media Group

[14] Majid, Abdul. 2014. Strategi Pembelajaran, Bandung. PT. Remaja Rosdakarya
[15] Moleong, Lexy J. 2013. Metode Penelitian Kualitatif. Bandung. PT. Remaja Rosdakarya.

[16] Morissan, A.M. 2010. Periklanan Komunikasi Pemasaran Terpadu, Jakarta. Penerbit Kencana.

[17] Nova, Firsan. 2011. Crisis Public Relations: Bagaimana PR Menangani Krisis Perusahaan. Jakarta. Grasindo

[18] Ruslan, Rosady. 2010. Manajemen Public Relations dan Media Komunikasi. Jakarta. Rajawali Pers.

[19] Siyoto, Sandu, Sodik, Ali. 2015. Dasar Metodelogi Penelitian, Yogyakarta. Literasi Media Publishing.

[20] Sugiyono, 2015. Metode Penelitian Kombinasi (Mix Methods). Bandung. Alfabeta

[21] Suprapto, Tommy. 2011. Pengantar Teori dan Manajemen Komunikasi. Yogyakarta. Media Pressindo.

[22] Umar, Husein. 2010. Management Strategic in Action, Jakarta. Rajawali Pers 
